Available online on 15.09 .2020 at http://jddtonline.info
Open Access to Pharmaceutical and Medical Research
(C) 2011-18, publisher and licensee JDDT, This is an Open Access article which permits
unrestricted non-commercial use, provided the original work is properly cited

Open $\odot$ Access

Research Article

\title{
The therapeutic effect of Cinnamomum cassia essential oil against hepatotoxicity induced by co-exposure to lead and manganese in developing Wistar rats
}

\author{
Djallal Eddine Houari ADLI 1*, Mostapha BRAHMI 1, Khaled KAHLOULA ${ }^{1}$, Wafaa ARABI 1, Bakhta BOUZOUIRA ${ }^{2}$, \\ Mustapha TALATIZI ${ }^{1}$, Miloud SLIMANI ${ }^{1}$ \\ 1. Laboratory of Biotoxicology, Pharmacognosy and Biological Valorisation of plants (LBPVBP) Department of Biology, Faculty of Natural and \\ Life Sciences, University of Dr Moulay Tahar - Saida - Algeria \\ 2. Department of Pathological Anatomy and Cytology, CHU of Sidi Bel Abbes, Algeria
}

\begin{abstract}
The present study was designed to evaluate the protective effect of Cinnamomum cassia essential oil (CCEO) on hepatotoxicity induced by coexposure to lead acetate $(\mathrm{Pb})(2.84 \mathrm{mg} / \mathrm{ml})$ and manganese chloride $(\mathrm{Mn})(4.79 \mathrm{mg} / \mathrm{ml})$ in developing Wistar rats. After we aning, rats exposed to $\mathrm{Pb}-\mathrm{Mn}$ received injections of Cinnamomum cassia essential oil $(0.1 \mathrm{ml} / \mathrm{kg})$ for 21 days. Extraction by hydrodistillation yielded $1.10 \%$ of $\mathrm{OECC}$ and the characterization of this oil by GC-MS indicates that the major components of this oil are: E-cinnamaldehyde (85.77\%), linalool (3.70\%), Z-cinnamaldehyde $(3.22 \%)$ and B-phellandréne $(1.19 \%)$. The concentration of lead and manganese in hepatocyte tissues was significantly increased compared to control rats. However, levels of hepatic markers such as Alanine aminotransferase (ALT), Aspartate aminotransferase (AST), alkaline phosphatase (ALP) were significantly increased in blood in $\mathrm{Pb}-\mathrm{Mn}$ poisoned rats. Pb-Mn-induced oxidative stress in liver tissue was indicated by decreased levels of superoxide dismutase, catalase and glutathione peroxidase respectively. Histologically, the liver showed several tissue alterations such as hepatocyte necrosis and the presence of steatosis foci. Administration of OECC considerably attenuated previous biochemical alterations as well as histological and cellular changes in liver tissue. In this study, we can conclude that the Cinnamomum cassia essential oil showed a hepatoprotective effect.
\end{abstract}

Keywords: Essential oil, Cinnamomum cassia, CG/MS, Hepatotoxicity, Lead acetate, Manganese chloride.

Article Info: Received 08 July 2020; $\quad$ Review Completed 16 Aug 2020; $\quad$ Accepted 23 Aug $2020 ; \quad$ Available online 15 Sep 2020

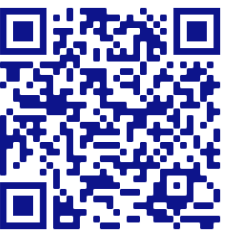

Cite this article as:

Adli DEH, Brahmi M, Kahloula K, Arabi W, Bouzouira B, Talatizi M, Slimani M, The therapeutic effect of Cinnamomum cassia essential oil against hepatotoxicity induced by co-exposure to lead and manganese in developing Wistar rats, Journal of Drug Delivery and Therapeutics. 2020; 10(5):49-55 http://dx.doi.org/10.22270/jddt.v10i5.4361

Djallal Eddine Houari ADLI, Laboratory of Biotoxicology, Pharmacognosy and Biological Valorisation of plants (LBPVBP) Department of Biology, Faculty of Natural and Life Sciences, University of Dr Moulay Tahar - Saida - Algeria

\section{INTRODUCTION}

Lead is an environmental and industrial pollutant. Its presence in human and animal tissues has often been associated with considerable health risks ${ }^{1}$. It alters the biology of the cell by disrupting many metabolic pathways and different physiological processes. It can alter certain neurobiological mechanisms that play a critical role in brain development ${ }^{2}$.

The manganese is at the same time an essential element for the living being and a toxic metal, considered as one of the most abundant elements on the terrestrial crust, indeed it is found in rocks, soil, water and food ${ }^{3}$. It has been discovered for centuries and used for various industrial applications. This element is recognized for its primary role in many enzymatic reactions as a cofactor or activator of numerous enzymes mainly localised in the brain as well as a regulator of the metabolism of lipids, proteins and amino acids in the organism 4 .

Although, for many toxic metals, there are effective detoxification chelators available. In parallel to the use of modern and especially synthetic drugs, it is also possible to use alternative and traditional medicine.

However, products like secondary metabolites by plants, essential oils intervene in many domains, they have found their place in aromatherapy, pharmacy, cosmetics and food preservation 5 . For decennia, Cinnamomum cassia has been used for its culinary and medicinal virtues. Other properties have been discovered, such as its anti-inflammatory, antioxidant, antimicrobial and anti-carcinogenic effect ${ }^{6}$. 
In the light of these data, our study aims at investigating the effect of the Cinnamomum cassia essential oil of bark intoxicated by lead acetate and manganese chloride on the liver in wistar rats during the development period (gestation and lactation).

\section{MATERIALS AND METHODS}

\section{Extraction and determination of the chemical} composition of the essential oil by GC/MS :

The cinnamon bark "Cinnamomum cassia" was bought and imported from Indonesia, then identified by taxonomic experts (Pr sitayeb). The sample was conserved, and the specimen voucher, coded P-200986, was deposited in the herbarium of the Biology Department of the Faculty of Science of the University of Saida, Algeria, for future reference. The analytical study of the essential oil of "Cinnamomum cassia" was carried out by gas chromatography type VARIAN CHROMPACK - CP 3900 by injection of $0.1 \mu \mathrm{l}$ of extract. The carrier gas used is helium He at a flow rate of $1.2 \mathrm{ml} / \mathrm{min}$. The column used is a CP type capillary column. Chrivasil-Dex CB Fusedsilica, $30 \mathrm{~m}$ long and $0,25 \mathrm{~mm}$ inner diameter. The thickness of the stationary is $0,25 \mu \mathrm{m}$; the temperature of the initial injection column is programmed at $70 \stackrel{\circ}{\circ} \mathrm{C}$ for $2,50 \mathrm{~min}$, then rises in steps of 5 ${ }^{\circ} \mathrm{C} / \mathrm{min}$ at $280{ }^{\circ} \mathrm{C}$; the detector used for this analysis is a mass spectrometry type detector (Saturn 2200) with a temperature of $280{ }^{\circ} \mathrm{C}$. The instrument is controlled by a menu-driven computer with software suitable for this type of analysis and a NIST database for compound identification.

\section{Preparation of the CCEO injection solution:}

A dose of $0.1 \mathrm{ml} / \mathrm{kg}$ of essential oil (EO) of Cinnamomum cassia ${ }^{7}$ was diluted in sterile bidistilled water $(100 \mu \mathrm{L})$ with one drop of tween $80^{8}$.

\section{Preparation of the oral solution:}

Lead acetate and manganese chloride tetrahydrate $\left(\mathrm{MnCl}_{2}\right.$ $4 \mathrm{H}_{2} \mathrm{O}$ ) are solubilised in bidistilled water at 2.84 and 4.79 $\mathrm{mg} / \mathrm{ml}$ respectively9.

\section{Distribution of Lots}

At day 0 of mating the rats are separated into two groups:

Group Mn-Pb: represents the rats co-exposed to manganese $\left(\mathrm{MnCl}_{2}\right)$ and lead acetate $\left(\mathrm{C}_{4} \mathrm{H}_{6} \mathrm{~Pb}_{2} \mathrm{H}_{2} \mathrm{O}\right)$ which receive them in bi-distilled water orally from the first day of mating until weaning.

Group C (control): consisting of rats which receive bidistilled water

At 21 days after giving birth, the rats are separated into 3 groups:

Group C (control): made up of young rats $(n=7)$ from the same mating which receive drinking water.

Group Pb-Mn: consisting of young rats (n=7) from the first mating which are given manganese chloride and lead acetate in bi-distilled water with physiological water administered intraperitoneally for 15 days after weaning.

Group Pb-Mn treated with CCEO: consisting of young rats $(\mathrm{n}=7)$ from the same mating which receive $\mathrm{Pb}-\mathrm{Mn}$ in bidistilled water with the injection solution administered intraperitoneally for 21 days after weaning.

\section{Body and liver weight}

The body weight of each animal was daily recorded throughout the duration of the experiment. The liver weights of different groups of animals were registered.

\section{Biochemical tests}

\section{The lead and manganese analysis in tissues of liver}

Depositing $1 \mathrm{~g}$ fresh weight of each sample with $1 \mathrm{ml}$ of nitric acid $\left(\mathrm{HNO}_{3}\right)$ at $65 \%$ purity, we bring the temperature to $95^{\circ}$ $\mathrm{C}$ for one hour, after cooling; we supplement the content to $4 \mathrm{ml}$ of double distilled water. The lead and manganese concentrations were determined in the liver by atomic absorption spectrophotometry (SHIMA DZU AA6200) and the values were expressed in $\mu \mathrm{g} / \mathrm{g}$.

\section{Determination of liver parameters}

Alanine aminotransferase (ALT), Aspartate aminotransferase (AST), alkaline phosphatase (ALP) according to the methods of Reitman and Frankle10. Determination of the concentrations of albumin, cholesterol and triglycerides by following the methods of Thomas ${ }^{11}$ and Fossati et Prencipe ${ }^{12}$ respectively.

\section{Measurement of antioxidant enzyme activity}

The rat liver was weighed and homogenized in a buffer solution containing $0.32 \mathrm{M}$ sucrose, $0.5 \mathrm{mM}$ EDTA, $10 \mathrm{mM}$ Tris-HCl (pH 7.4) in ice (1mg tissue /4 $\mathrm{ml}$ buffer solution) using a glass/glass homogenizer. The fabrics were maintained at $4^{\circ} \mathrm{C}$ during all dissection and homogenization procedures. The homogenate was centrifuged at $1000 \mathrm{xg}$ for 15 minutes at $4^{\circ} \mathrm{C}$. The supernatant thus obtained was centrifuged at $10000 \mathrm{xg}$ for 15 minutes at $4^{\circ} \mathrm{C}$. The pellet constitutes the mitochondrial fraction and supernatant is re-centrifuged at $10,000 \mathrm{~g} / 30$ minutes Both pellets thus obtained are solubilized in a buffer solution containing $0.32 \mathrm{M}$ sucrose, $0.5 \mathrm{mM}$ EDTA, $10 \mathrm{mM}$ Tris- $\mathrm{HCl}$ and $0.02 \%$ digitonin (pH 7.4), digitonin is added to release all imprisoned mitochondria in the synaptosomes and centrifuged a second time at $10000 \times \mathrm{g}$ for $15 \mathrm{mn}$ at $4^{\circ} \mathrm{C}$, the pellet thus obtained constitutes the fraction of the total mitochondria which will be solubilized in a solution containing sucrose $(0.32 \mathrm{M} \text { at } \mathrm{pH} 7.4)^{13}$. Super oxidize dismutase (SOD) (EC 1.15.1.1) was analyzed on supernatant using the technique of Wenqiang et al .14; this method is based on inhibition of formation of adenine nicotinamide dinucleotide, phenazine methosulfate and formazan amino tetra zoliumblue. Activities and levels of antioxidants at the brain level such as catalase (CAT), glutathione peroxidase (GPx) were analyzed by the Karousou et al .15; Jollow et al.13 methods respectively.

\section{Histological study}

Samples of liver spleen were collected and fixed in $10 \%$ buffered neutral formalin solution, dehydrated in gradual ethanol (70-100\%), cleared in xylene, and embedded in

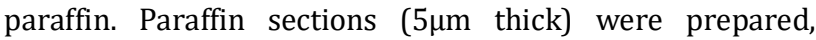
routinely stained with hematoxylin and eosin (H\&E) dyes, and then examined microscopically 16

\section{Expression and statistical analysis of results}

The results are expressed as the mean (M) of the individual values, assigned from the standard error to the mean (SEM). The comparison of several means is carried out by an analysis of variance (one wayAnova) with the intoxication factor (Pb-Mn, C). Repeated-measure Anova were used for time factor analysis. A probability $\mathrm{p}<0.05$ is considered significative. Statistical analyses were performed using Sigma Stat software (SPSS Inc., Chicago, IL, USA).

\section{RESULTS AND INTERPRETATIONS}




\section{The yield of essential oil}

After hydro-distillation of the Cinnamomum cassia plant material. The yield obtained by the report between the weight of oil extracted and the weight of plant matter used, expressed as a percentage (\%) is equivalent to $1.1 \%$.

\section{Principal Essential Oil Compounds Detected GC/MS}

The analysis of the essential oil of Cinnamomum cassia by gas chromatography identified 14 major compounds listed in Table 01 in order of elution.14 components representing the sum of the percentages of the components obtained were identified of which $88.995 \%$ are aromatic aldehydes, 6.148 $\%$ are monoterpenic hydrocarbons, $4.077 \%$ are terpenic alcohols and $0.780 \%$ are phenols. The major components of this oil are: E-cinnamaldehyde (85.77\%), linalool (3.707\%), Z-cinnamaldehyde (3.22\%) and B-phenol (1.19\%).

\section{Effect of Pb-Mn on body and liver weight:}

The body weight results show that animals co-exposed to $\mathrm{Pb}-\mathrm{Mn}$ showed a significant $(\mathrm{p}<0.05)$ decrease in body weight compared to control animals during the experiment. Animals exposed to pb-Mn and treated with OECC showed a significant $(\mathrm{p}<0.05)$ increase in body weight compared to untreated poisoned rats (Table 02). The results found in the poisoned animals also showed a significant $(\mathrm{p}<0.05)$ decrease in liver weight relative to controls (Table 02). In contrast, animals that were treated with OECCs showed a significant $(\mathrm{p}<0.05)$ increase in liver weight compared to poisoned rats.

\section{Biochemical determination}

\section{Determination of lead and manganese levels in liver tissue}

The results obtained from lead and hepatic manganese determinations using atomic absorption spectrophotometry (AAS), are significantly $(\mathrm{p}<0.05)$ increased in $\mathrm{Pb}-\mathrm{Mn}$ poisoned rats. These levels are decreased following administration of the plant extract in the batch of previously intoxicated rats (Pb-Mn-CCEO) (Table 03).

\section{Liver function}

Biochemical analysis of liver biomarkers at the end of the experiment showed significant elevations in ALT, AST, total bilurbine and alkaline phosphatase in rats exposed to $\mathrm{Pb}-\mathrm{Mn}$ compared with controls (Table 03). After the duration of treatment with OECC, there was a marked correction in plasma levels of these liver parameters in previously intoxicated rats.

\section{Liver activity of oxidative status enzymes}

The liver oxidative status results show a significant decrease in liver SOD, CAT and GPx in rats exposed to $\mathrm{Pb}-\mathrm{Mn}$ during the developmental period compared to control rats. While a significant elevation is observed $(\mathrm{p} \leq 0.05)$ under the action of OECC in the treated lot following intoxication (Table 04).

\section{Effect of Pb-Mn on the structural architecture of the liver}

Histological sections of the livers of $\mathrm{Pb}-\mathrm{Mn}$ intoxicated rats show necrosis and hepatic parenchyma with swelling, ballooning of hepatocytes and lipid vacuoles in the hepatocytes producing foci of steatosis (Figure 01.B) compared to the livers of control rats.

Similarly, the histopathological study of liver samples from intoxicated rats showed a striking feature as shown in Figure 01 (B1):

- Inflammatory infiltrate around the portal spaces.
The treatment of rats exposed to $\mathrm{Pb}-\mathrm{Mn}$ with $\mathrm{C}$. cassia EO revealed a hepatic parenchyma with portal inflammation. In addition, the hepatocytes showed signs of regeneration: large binucleated hepatocytes with granular cytoplasm (Figure 01.C).

\section{DISCUSSION}

Our results show that EO from Cinnamomum cassia obtained by hydrodistillation has a yield of $1 \%$, which is in accordance with the work of 17 and ${ }^{18}$ who reported a yield between (0.4$4.9 \%$ ). In addition, the GPG-MS of this condiment contains primarily an essential oil with various chemical components of various natures such as E-cinnamaldehyde (85.775\%), linalool (3.707\%), Z-cinnamaldehyde (3.22\%) and Eugenol $(0.48 \%)$ these results corroborate with those of Sariözkan et al. 2016 who show that E-cinnamaldehyde has a percentage of $88.2 \%$ in their study.

\section{Impact of lead and manganese on biochemical parameters}

The use of atomic spectrophotometry allowed us to record high blood lead levels in rats co-exposed to $\mathrm{Pb}-\mathrm{Mn}$ during gestation and lactation. These results show a good impregnation of lead, which means that the liver is one of the preferred sites for lead binding ${ }^{19}$.

In addition, the level of $\mathrm{Mn}$ in tissues is an effective biomarker and representative of the exposure of the latter. The amount of Mn is highest (about 66\%), with a half-life of 37 days $^{20}$. The level of Mn found in this study is significantly elevated in poisoned rats compared to control rats. However, studies have shown that during pregnancy, blood levels of $\mathrm{Mn}$ increase over the three semesters and $\mathrm{Mn}$ enters the placenta via active transport ${ }^{21}$ the increase in $\mathrm{Mn}$ levels during pregnancy may also be related to accelerated erythropoiesis, intestinal absorption, or tissue mobilization of $\mathrm{Mn}^{22}$. Tholin et al. ${ }^{23}$ also reported that Mn levels during pregnancy increase with each trimester.

\section{Effects of Pb-Mn on liver function tests}

ALT and AST are sensitive indicators of acute hepatic necrosis due to $\mathrm{Pb}{ }^{24}$

Through our study a significative increase in ALT and AST levels in $\mathrm{Pb}-\mathrm{Mn}$ poisoned rats during pregnancy and lactation was observed compared to control rats, which could explain why $\mathrm{Pb}$ binds to plasma proteins, where it causes alterations in a large number of enzymes. It may also disrupt protein synthesis in hepatocytes 25 .

However, the liver is an important target for lead. Lead has a high affinity for protein thiol groups in liver cell membranes, leading to liver necrosis and the output of ALT and AST in serum. These two parameters are indicative of cell leakage and loss of functional integrity of the hepatocyte cell membrane. This result is confirmed by the work of 26 . Our results are in agreement with the authors who reported that lead has a hepatotoxic effect 27 .

In fact, Upadhyay et $\mathrm{al}^{28}$ demonstrated that rats nourished with lead contaminated food experience oxidative stress related to elevated serum ALT and AST and alkaline phosphatase (PAL) levels. This phenomenon is due to the accumulation of amino acids such as alanine and glutamic acid resulting from the degradation of somatic proteins. These amino acids are transformed under the action of aminotransferases into ketone bodies and then into glucose (neoglucogenesis).

In addition, the liver is a critical organ for the regulation of Mn homeostasis in the body. Furthermore, Mn toxicity is 
rare and manifests itself mainly in the liver, probably due to the primary role that this organ plays in eliminating $\mathrm{Mn}$ from the blood through biliary excretion ${ }^{29}$. Consumption of Mncontaminated water causes the liver to overflow, which can lead to liver damage ${ }^{30}$.

The work of Fordahl et al. ${ }^{31}$. indicates that a wide exposure to $\mathrm{Mn}$ has an effect on hepatic metabolites, mainly by causing disturbances in lipid metabolism and thus the excessive formation of oleic acid, hydroxybutyric acid and ketones, the latter being in surplus in the blood will be eliminated in the urine, adding that alterations in hepatic metabolites were correlated with the tissue increase in manganese and the decrease in iron levels.

Exposure to $\mathrm{Pb}-\mathrm{Mn}$ during gestation and lactation increases total bilirubin and alkaline phosphatase levels in poisoned animals compared to control animals. This is similar to the work of Nabil et al. ${ }^{32}$. Which justify this elevation by the induction of the enzyme heme oxygenase which converts heme into bilirubin, the latter being transported in the liver as a complex with the serum. Then, bilirubin is conjugated with glucoronide in the liver under the toxic effect of lead, this conjugation with bilirubin renders it inactive. In addition, bilirubin has a protective role against metalinduced oxidative damage to the cell membrane ${ }^{33}$.

In addition, the evaluation of the toxicity of $\mathrm{Pb}$ and $\mathrm{Mn}$ was expressed by the assay of antioxidant enzymes, namely CAT, GPx, SOD. Knowing that these antioxidant enzymes help maintain the homeostasis of redox potential ${ }^{34}$.

The analysis of tissue antioxidant status indicated that $\mathrm{Pb}$ Mn decreases the enzymatic activities of catalase (CAT), superoxide dismutase (SOD) and Glutathione peroxidase (GPx), leading to a dysfunction of the antioxidant defense system. Therefore, $\mathrm{Pb}$ can affect the antioxidant barrier by inhibiting the functional thiol groups of enzymes such as SOD 35 . This metal has been reported to alter the antioxidant system of tissues in proportion to the amount of lead ingested 36 .

Bhattacharjee et al. ${ }^{37}$. show that exposure to high dose Mn induces oxidative damage leading to altered activity of the enzymes SOD, CAT, GPx, and expression of Mn-SOD and GPx genes.

It is suggested that the first step in the production of ROS is the production of $\mathrm{O} 2$ which can be converted to $\mathrm{H} 2 \mathrm{O} 2$ by $\mathrm{Mn}$ and $\mathrm{Cu} / \mathrm{Zn}$ superoxide dismutase in the mitochondria and cytoplasm. $\mathrm{H} 2 \mathrm{O} 2$ can be further converted to $\mathrm{OH}$. in the presence of $\mathrm{Mn}$ or other transition metals ${ }^{38,39}$.

The Mn2+ interferes with the homeostasis of $\mathrm{Ca} 2+$ in the mitochondria by occupying the $\mathrm{Ca} 2+$ binding sites with the generation of oxidative stress, leading to the induction of a process called mitochondrial permeability transition. The opening of a permeability transition port leads to the solubility of the mitochondrial membrane for ions and protons which cause the rapid swelling and ultrastructure change associated with the loss of mitochondrial potential of the inner membrane, altered oxidative phosphorylation, ATP synthesis ${ }^{40}$.

\section{The Effect of $\mathrm{Pb}$ and $\mathrm{Mn}$ on the structural architecture of the liver}

The results obtained after microscopic observation of histological sections made in the liver in rats intoxicated with $\mathrm{Pb}$ and/or $\mathrm{Mn}$ showed necrosis with inflammatory infiltrate, hepatocytes and lipid vacuoles within the hepatocytes producing foci of steatosis compared to controls. These results are similar to the studies of Jarrar et al.41 which suggest that subchronic exposure to lead produces liver damage in rats due to disruption of the antioxidant defense system by free radical generation and oxidative stress, they revealed that lead toxicity leads to free radical damage by two distinct pathways: (1) the generation of ROS, including hydroperoxides, singlet oxygen and hydrogen peroxide and (2) the direct depletion of antioxidant reserves. These results indicate that the hepatic effects of lead were manifested by abnormal serum enzyme levels. The appearance of inflammatory cells in liver tissue due to sub-chronic lead exposure may suggest that lead may interact with proteins and enzymes in the liver interstitial tissue interfering with the antioxidant defense mechanism and leading to reactive oxygen species (ROS) which in turn may mimic an inflammatory response ${ }^{42}$.

In fact, the liver is the critical organ for the regulation of Mn homeostasis in the body. Furthermore, Mn toxicity is rare and manifests itself primarily in the liver, probably due to the primary role that this organ plays in eliminating Mn from the blood through biliary excretion ${ }^{29}$, consumption of Mncontaminated water causes the liver to overflow, which can lead to liver damage ${ }^{30}$.

After administration of Cinnamomum cassia essential oil by intraperitoneal (IP) voice to rats co-exposed to $\mathrm{Pb}-\mathrm{Mn}$, a clear improvement in the various biochemical parameters of the intoxicated rats treated with aromatherapy compared to the intoxicated rats was observed. This is due to the different therapeutic and prophylactic virtues of OECC.

However, Chou et al. 34 showed that C.cassia EO and cinnamaldehyde, which is its major constituent, have the ability to repress oxidative stress and lipid peroxidation as they interfere with each other by improving the activity of cellular GSH, CAT and GPx, which allows to reduce the rate of ROS. However, Liao et al. ${ }^{43}$ reported that cinnamaldehyde is the component responsible for modifying the level of antioxidant enzymes resulting from oxidative stress. These results may demonstrate that CCEO may have beneficial effects on certain health problems including their antioxidant, anti-inflammatory, antimicrobial and anticarcinogenic powers. On the other hand, they may even reduce the risk of cardiovascular and neurological diseases ${ }^{44}$ and metabolic disorders ${ }^{45}$.

According to our results, histological examination of the livers of the intoxicated rats treated showed a hepatic parenchyma remodelled by hepatic steatosis made up of hepatocyte cells containing lipid inclusions in their cytoplasm. Studies suggest that cinnamaldehyde, which is the major component of C.cassia, has effects. The antiinflammatoires mechanism of cinnamaldehyde may be related to ROS and is associated with increased activity of antioxidant enzymes (CAT and GPx). Cinnamaldehyde can be used as a pharmacological agent in the prevention or treatment of a disease in which free radical formation in a pathogenic factor occurs 43 .

Table 1: Concentration in $\%$ and retention time of the different compounds obtained by gas chromatographic analysis of the essential oil of Cinnamomum cassia. 


\begin{tabular}{|c|c|c|}
\hline Compound & Retention time (min) & Concentration (\%) \\
\hline E-cinnamaldehyde & 22.26 & 3.70 \\
\hline Linalol & 15.10 & 3.22 \\
\hline Z-cinnamaldehyde & 22.60 & 1.71 \\
\hline p-cymene & 06.68 & 1.19 \\
\hline$\beta$-Phellandrene & 6.121 & 1.189 \\
\hline Limonene & 9.81 & 0.48 \\
\hline Eugenol & 24.01 & 0.395 \\
\hline$\alpha$ pinene & 10.70 & 0.37 \\
\hline Terpiene-4-ol & 16.70 & 0.30 \\
\hline Chavical & 21.77 & 0.291 \\
\hline$\gamma$-terpinene & 10.10 & 0.184 \\
\hline Camphene & 12.55 & 0.109 \\
\hline$\beta$-pinene & 10.80 & 0.080 \\
\hline$\alpha$-Phellandrene & 7.29 & \\
\hline
\end{tabular}

Table 2: Evaluation of body weight parameters of control rats, $\mathrm{Pb}-\mathrm{Mn}$, and treated with C.cassia essential oil

\begin{tabular}{|c|c|c|c|c|}
\cline { 2 - 5 } \multicolumn{1}{c|}{} & Organ & C & Pb-Mn & Pb-Mn+CCEO \\
\hline Body weight (g) & & $95,03 \pm 1,70$ & $67,88 \pm 1,35^{*}$ & $76,17 \pm 1,28$ \\
\hline Relative weight (g) & Liver & $8,63 \pm 0,4$ & $6,33 \pm 0,9^{*}$ & $6,53 \pm 0,2$ \\
\hline
\end{tabular}

The values are expressed in mean $\pm \operatorname{SEM}(*: \mathrm{p}<0.05)$.

Table 3: Effect of C.cassia essential oil on different biochemical parameters in $\mathrm{Pb}-\mathrm{Mn}$ intoxicated rats compared to control rats.

\begin{tabular}{|c|c|c|c|}
\cline { 2 - 4 } \multicolumn{1}{c|}{} & $\mathbf{C}$ & Pb-Mn & Pb-Mn+CCEO \\
\hline Pb $(\boldsymbol{\mu g} / \mathbf{g})$ & $0,15 \pm 0,08$ & $7,02 \pm 0,05^{*}$ & $3,4 \pm 0,09^{*}$ \\
\hline Mn ( $\boldsymbol{M g} / \mathbf{g})$ & $84,6 \pm 1,08$ & $118,6 \pm 0,71^{*}$ & $89,3 \pm 1,01^{*}$ \\
\hline ALT (UI/l) & $22,11 \pm 0,15$ & $48,14 \pm 0,35^{*}$ & $29,50 \pm 0,46$ \\
\hline AST (UI/l) & $14,70 \pm 0,20$ & $45,97 \pm 0,19^{*}$ & $22,63 \pm 0,16^{*}$ \\
\hline Total Bilturbine (mg/dl) & $0,87 \pm 0,04$ & $1,17 \pm 0,01^{* *}$ & $0,90 \pm 0,02^{* *}$ \\
\hline Alkaline phosphatase (IU /l) & $44,39 \pm 0,20$ & $97,83 \pm 0,21^{*}$ & $49,66 \pm 0,32^{*}$ \\
\hline
\end{tabular}

The values are expressed in average $\left.\pm \operatorname{SEM}^{* *}: \mathrm{p}<0.01,{ }^{*}: \mathrm{p}<0.05\right)$.

Table 4: Effect of essential oil of C.cassia in the activity of anti-oxidant enzymes in liver of rats intoxicated.

\begin{tabular}{|c|c|c|c|}
\hline Groups & C & Pb-Mn & Pb-Mn+CCE0 \\
\hline SOD (U/mg) & $0,71 \pm 0.059$ & $1,19 \pm 0,03^{*}$ & $0,89 \pm 0,019^{*}$ \\
\hline CAT (U/mg) & $0,39 \pm 0,34$ & $0,75 \pm 0,15^{*}$ & $0,55 \pm 0,04^{*}$ \\
\hline GPx (Um/g) & $0,83 \pm 0,07$ & $1,38 \pm 0,23^{*}$ & $0,97 \pm 0,04^{*}$ \\
\hline
\end{tabular}

The values are expressed in mean $\pm \operatorname{SEM}(*: \mathrm{p}<0.05)$. 

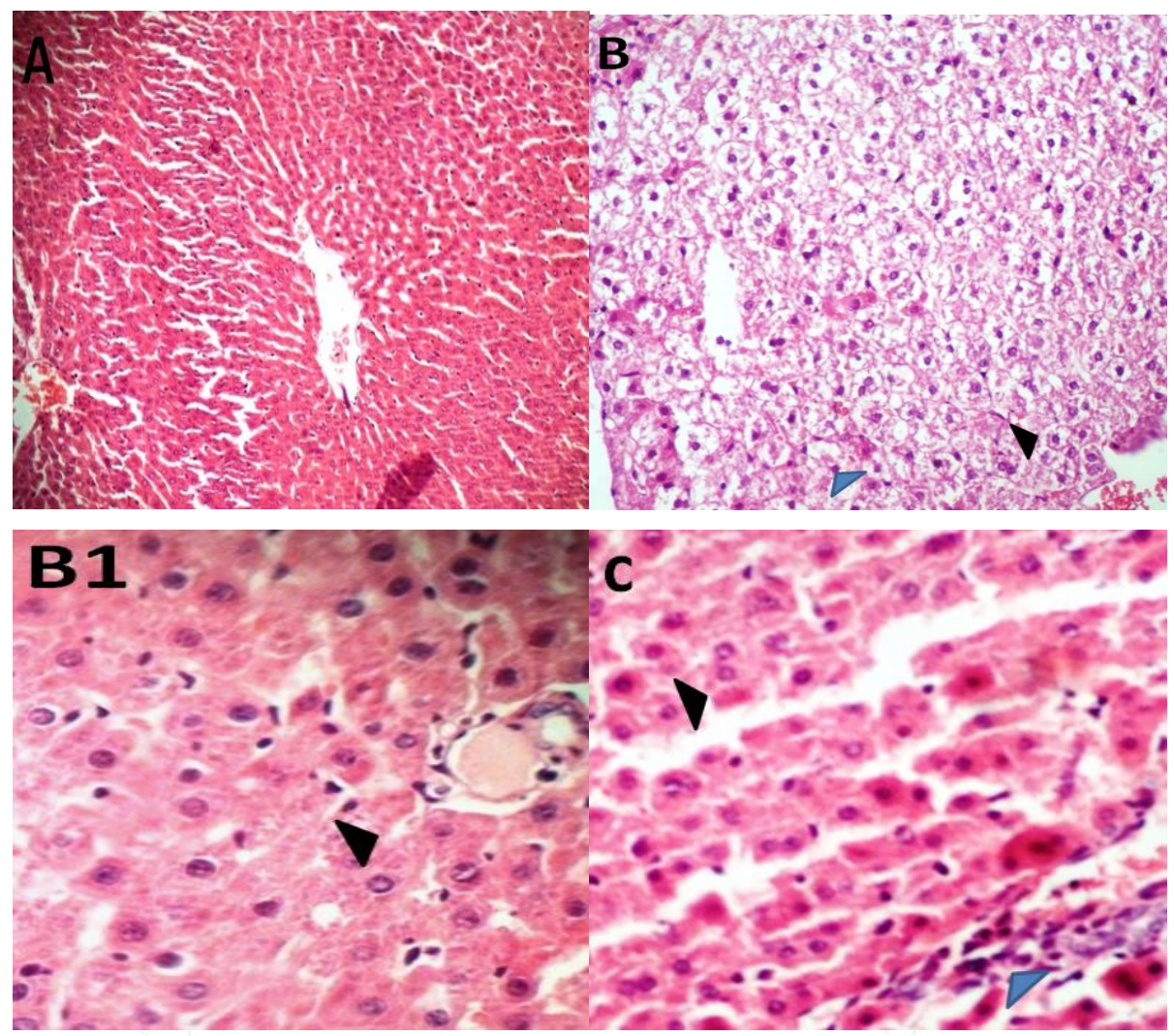

Figure 1: Optical microscopy of liver tissue stained with hematoxylin and eosin G:( $x$ 40). (A)G:( $x$ 100)in sections of the livers of control rats appeared with normal architecture.(B) Rats co-exposed to Pb-Mn showed hepatic necrosis (black arrow), steatosis (blue arrow).(B1) Rats exposed to Pb-Mn showed portal inflammation (black arrow).(C) Rats exposed to Pb-Mn and treated with C. cassia EO showed regenerating hepatocytes (black arrow), portal inflammation (blue arrow).

\section{CONCLUSION}

Exposure of Wistar rats during gestation and lactation to $\mathrm{Pb}$ Mn revealed hepatotoxic effects resulting in a significant alteration of the antiradical system represented by the various enzymes. Treatment with OECC in previously intoxicated rats showed a significant improvement in the histopathological image of the liver as well as liver function.

\section{REFERENCES}

[1] Juberg DR, Kleiman CF, Simona CK, Position paper of the American Council on Science and Health: lead and human health, Ecotoxicol Environ Saf., 1997; 38:162-80.

[2] Marco J, Zabay J, Garcia-Marco M A, Gomez G, Mul J M, Munar MA, Soler J and Viader C, AngiotensinogeneT174M polymorphism: opposite relationships with essential hypertension and obesity in a homogenous population from Majorca (Baleric islands, spain), Nefrologia., 2005; 25:629-36.

[3] Santos D, Milatovic D, Andrade V, Batoreu MC, Aschner M, Marreilha dos Santos AP, The inhibitory effect of manganese on acetylcholinesterase activity enhances oxidative stress and neuroinflammation in the rat brain, Toxicology., 2012; 26:292(2-3):90-8.

[4] Lebda M, El-Neweshy MS, El-Sayed YS, Neurohepatic Toxicity of subacute manganese chloride exposure and potential chemoprotective effects of lycopene, NeuroToxicology., 2012; 33: 98-104.

[5] Teixeira B, Marques A, Ramos C, Neng NR, Nogueira JM, Saraiva JA and Nunes ML, Chemical composition and antibacterial and antioxidant properties of commercial essential oils, Ind Crops Prod., 2013; 43:587-595.

[6] Hamidpour R, Hamidpour M, Hamidpour S \& Shahlari M, Cinnamon from the selection of traditional applications to its novel effects on the inhibition of angiogenesis in cancer cells and prevention of Alzheimer's disease, and a series of functions such as antioxidant, anticholesterol, antidiabetes, antibacterial, antifungal, nematicidal, acaracidal, and repellent activities, Journal of traditional and complementary medicine., 2015; 5(2):66-70.

[7] Li S, Wang C, Peng X, Wu X, Effects of Aqueous Extracts and Essential Oil from Cinnamomum cassia on Rat Colonic Mucosal Morphology and Bacteroidales, Journal of Food and Nutrition Research., 2013; 1(2):7-12.

[8] Halder S, Mehta AK, Kar R, Mustafa M, Mediratta PK and Sharma KK, Clove oil reverses learning and memory deficits in scopolamine-treated mice, Planta Medica., 2011; 77(8):8304.

[9] Molina RM, Phattanarudee S, Kim J, Thompson K, WesslingResnick M, Maher TJ and Brain JD, "Ingestion of Mn and Pb by Rats during and after Pregnancy Alters Iron Metabolism and Behavior in Offspring",Neu roToxicology., 2011; 32(4):413-422.

[10] Reitman S, Frankle S, Coloremetric method for determination of serum transaminase activity, American Journal of Clinical Pathology., 1957; 28:56-68.

[11] Thomas C, Thomas L, (1992). Labor diagnostik v on Erkrankung en der Nier en und ableitendenHar (hrsg) Dans: Thomas L, 6 éd. Philadelphi, Labor und Diagnose.

[12] Fossati P, Prencipe L, Serum triglycerides determined colorimetrically with an enzyme that produces hydrogen peroxide, Clinical Chemistry., 1982; 28:2077-2080.

[13] Jollow DJ, Mitchell JR, Zampaglione N, et al, Bromobenzene-induced liver necrosis. Protective role of glutathione and evidence for 3,4-bromobenzene oxide as the hepatotoxic metabolite, Pharmacology., 1973; 11:151-69

[14] Wenqiang G, Shufen L, Ruixiang Y, et al, Comparison of essential oils of clove buds extracted with supercritical carbon dioxide and other three traditional extraction methods, Nat Prod Res., 2006; 20:992-8

[15] Karousou R, Koureas DN, Kokkini S, Essential oil composition is related to the natural habitats: Corido Thymus capitatus and Satureja thymbra in Natura 2000, Phytochemistry., 2005; 66:2668-73

[16] Suvarna SK, Layton C, Bancroft JD, (2013). Bancroft's theory and practice of histological techniques. 7 th Ed. England: Churchill Livingstone. Elsevier. 
[17] Krishnamoorthy BT, JOHN ZA, Rema J, \& Mathew PA, Evaluation of selected Chinese cassia (Cinnamomum cassia Blume) accessions for chemical quality, Journal of Spices and Aromatic Crops., 1999; 8(2):193-195.

[18] Linsheng W, Yafang Z, and Boquan J, Comparison of Microwave-assisted Hydrodistillation with the Traditional Hydrodistillation Method in the Extraction of Essential Oils from Dwarfed Cinnamomum Camphora var ,Linaolifera Fujita Leaves and Twigs, J ,Adv. J,Food Sci,Technol., 2013; 5(11): 14361442.

[19] Goullé JP, Saussereau E, Lacroix C, and Guerbet M, Toxicologie et pharmacologie médico-légales.Paris Elsevier ; 2012 ; 189232

[20] Lee BK, \& Kim Y, Relationship between blood manganese and blood pressure in the Korean general population according to KNHANES 2008, Environmental research., 2011;111(6): $797-$ 803.

[21] Krachler M, Rossipal E, \& Micetic-Turk D, Trace Element Transfer from the Mother to the Newborn-Investigations on Triplets of Colostrum, Maternal, and Umbilical Cord Sera, In Trace Elements in Man and Animals., 2002; 10:(365-368).

[22] Chowdhury TR, Mandal BK, Samanta G, Basu GK, Chowdhury PP, Chanda CR \& Saha KC, Arsenic in groundwater in six districts of West Bengal, India: the biggest arsenic calamity in the world: the status report up to August, 1995, In Arsenic.,1997; (93-111).

[23] Tholin K, Palm R, Hallmans G, \& Sandström B, Manganese status during pregnancy, Annals of the New York Academy of Sciences., 1993; 678(1):359-360.

[24] Mehana EE, Meki AMA, And Fazili KM, Ameliorated effects of green tea extract on lead induced liver toxicity in rats, Exp. Toxicol. Pathol., 2010; Doi: 10: 1016 / J. etp

[25] Shalan MG, Mostafa MS, Hassouna MM, El-Nabi SE, El-Refaie A Amelioration of lead toxicity on rat liver with vitamin $\mathrm{C}$ and silymarin supplements, Toxicology., 2005; 206:1-15.

[26] Lombardi PE, Peri SI, \& Guerrero NRV, ALA-D and ALA-D reactivated as biomarkers of lead contamination in the fish Prochilodus lineatus, Ecotoxicology and environmental safety.,2010; 73(7):1704-1711.

[27] Ibrahim NM, Eweis EA, El-Beltagi HS and Abdel Mobdy YE, Effect of lead acetate toxicity on experimental male albino rats, Asian Paci. J. Trop.Biomed., 2012; 41-46.

[28] Upadhyay Ak, Mathur R, Bhadauria M and Nirala Sk, Therapeutic influence of zinc and ascorbic acid against lead induced biochemical alterations, Thérapie., 2009; 64(6):383388.

[29] Crossgrove J, and Zheng W,.Manganese toxicity upon overexposure, NMR Biomed., 2004; 17:544-553.

[30] Peili H , Chunxia C , Hui W , Guojun L , Haiming J , Ying H, Na LiuYX, Qiuhong Y, Yuting L, Pengwen W, Zhixiong S, Zhiwei S, Manganese effects in the liver following subacute or subchronic manganese chloride exposure in rats, Ecotoxicology and Environmental Safety., 2011; (74):615-622.
[31] Fordahl S, Cooney P, Qiu Y, Xie G, Jia W, and Erikson KM, Waterborne manganese exposure alters plasma, brain, and liver metabolites accompanied by changes in stereotypic behaviors, Neurotoxicol Teratol., 2012; 34(1):27-36.

[32] Nabil M, Ibrabim E A, Eweis H, and Yasmin E, Effect of lead acetate toxicity on experimental male albino rate, Asian pacific journal of tropical biomedicine., 2012; 41-46.

[33] Noriega GO, Tomaro ML, and Del Battle AM, Bilirubin is highly effective in preventing in vivo delta - aminolevulinic acid induced oxidative cell damage, Biochem. Biophys. Acta., 2003; 1638(2):173-178.

[34] Chou ST, Chang WL, Chang CT, Hsu SL, Lin YC, \& Shih Y, Cinnamomum cassia essential oil inhibits $\alpha$-MSH-induced melanin production and oxidative stress in murine B16 melanoma cells, International journal of molecular sciences., 2013; 14(9):19186-19201.

[35] Patrick GW, Anderson WJ, and Brophy P, Dendritic alterations of cortical pyramidal neurons in postnatally lead-exposed kittens: a Golgi-Cox study, Dev Neurosci., 1995; 17:219-229.

[36] O'Flaherty EJ, Adams WD, Hammond PB, Taylor E, Resistance of the rat to development of lead-induced renal functional deficits , J Toxicol. Environ., 1986; 18:61-75.

[37] Bhattacharjee P, Banerjee M, \& Giri AK, Role of genomic instability in arsenic-induced carcinogenicity. A review. Environment international., 2013; 53:29-40.

[38] Goldstein S, Meyerstein D, and Czapski G, The Fenton reagents, Free Radical Biology \& Medicine., 1993; 15:435-445.

[39] Martinez-Finley EJ, Gavin CE, Aschner M, \& Gunter TE, Manganese neurotoxicity and the role of reactive oxygen species, Free Radical Biology \& Medicine., 2013; 62:65-75.

[40] Farina M, Avila DS, da Rocha JB, and Aschner M, Metals, oxidative stress and neurodegeneration: A focus on iron, manganese and mercury, Neurochemistry International., 2012; 62:575-594.

[41] Jarrar BM, Taib NT, Histological and histochemical alterations in the liver induced by lead chronic toxicity, Saudi Journal of Biological Sciences., 2012; 19:203-210.

[42] Johar D, Roth JC, Bay GH, Walker JN, and Kroczak TJ, Los M, Inflammatory response, reactive oxygen species, programmed (necrotic-like and apoptotic) cell death and cancer, Rocz, Akad, Med, Bialymst., 2004; 49:31-39.

[43] Liao JC, Deng JS, Chiu CS, Hou WC, Huang SS, Shie PH, \& Huang GJ, Anti-inflammatory activities of Cinnamomum cassia constituents in vitro and in vivo. Evidence-Based Complementary and Alternative Medicine, (2012).

[44] Rao PV, and Gan SH, Cinnamon:A Multifaceted Medicinal Plant ,Evidence Based Complementary and Alternative Medicine., 2014; 1-12.

[45] Yong-Ming Y, Ping F, Mu-Tian Y, Ning L, Qing L and YongXian C, Anti-diabetic nephropathy compounds from Cinnamomum cassia, Journal of Ethnopharmacology., 2015 . (165):141-147. 